\title{
RÁDIO E MÚSICA POPULAR NOS ANOS 30
}

\author{
José Geraldo Vinci de Moraes \\ UNESP-Cepel
}

RESUMO: A cidade de São Paulo na década de 1930 passou por profundas transformações culturais. As manifestações das culturas populares urbanas presentes na cidade obviamente tiveram papel importante nesta nova realidade histórica. Com relação à música, os elementos próprios do universo urbano-moderno como o rádio, o disco, a relativa profissionalização dos artistas, a lógica dos espetáculos e a imprensa especializada, que despontavam de forma ascendente entre o final dos anos vinte e a década de 1930, foram determinantes na alteração dos modos de produção e difusão da música popular, e por conseqüência, nas formas de sentir, refletir e ver a cidade. Esse quadro de permanente extensão das formas de entretenimento, iniciado na passagem do século, se consolidou na década de 1930, principalmente em razão dessa expansão da indústria fonográfica e, sobretudo, radiofônica e suas derivações imediatas.

PALAVRAS-CHAVE: São Paulo, Década de 1930, Música Popular, Rádio, Cultura Popular

ABSTRACT: In the 1930's the city of São Paulo went through profound cultural transformations. The manisfestations of urban popular cultures, present in the city obviously had important roll in this new historical reality.

With regard to music, the elements peculiar to the modern-urban universe, wherein, the radio, the record, the relative professionalizing of artists, the logic of shows and the especialized press, that rouse in na ascendent way in the late 1920's and the 1930's where determinative on the alteration of the popular music way of production and diffusion and as a consequence on the ways to feel, reflect and sight the city. That picture of permanent extention of the entertaibment forms, iniciated on the passage of the century, consolidated in the 1930's, mainly due to this expansion immediate derivations. KEYWORDS: São Paulo, Decade of 1930, Popular Music, Radio, Popular Culture 
O quadro de permanente extensão das formas de entretenimento popular e urbano vinculados à música popular, iniciado no Brasil durante a passagem do século $^{1}$, consolidou-se nos anos 30 , principalmente com a expansão da indústria radiofônica e fonográfica e suas derivações imediatas como a profissionalização dos artistas populares, a multiplicação dos espetáculos, as revistas especializadas etc. Artistas e músicos de maneira geral, e os populares de forma especial, tiveram condições de ampliar e conquistar novos espaços de sobrevivência e de divulgação de sua produção. As empresas radiofônicas tornaram-se os principais locais de concentração do músico popular profissional. As emissoras rapidamente constituíram-se no eixo fundamental de propagação da música popular, alterando conseqüentemente a produção artística musical.

A cidade de São Paulo, especialmente, apresentava, desde o início do século, um cenário musical bastante fragmentado e de múltiplas características, acompanhando o ritmo geral das transformações sociais e culturais da cidade. Marcada por diversas transições e fusões entre as tradições musicais das festas populares religiosas e profanas rurais, a cultura negra africana, e dos imigrantes (principalmente italianos), a música popular paulistana começou a ser produzida e divulgada por uma extensa e crescente estrutura de difusão que revelava e apontava para um certo cosmopolitismo (MORAES, 1997). A radiofonia paulistana acompanhou, de maneira geral, essa complexa identidade fundada num cosmopolitismo bastante difuso.

Na realidade, o rádio paulistano apontou nos anos 30 marcado por questões político-regionais, mas rapidamente ele foi capaz de desenvolver-se além des-

\footnotetext{
${ }^{1}$ Na realidade, esse foi um fenômeno social mais amplo iniciado na segunda metade do século XIX, que se estendeu até o começo do XX está intimamente vinculado às realidades das grandes metrópoles. HOBSBAWN, 1990, p. 59 e 60.
}

ses limites. Em poucos anos de atividades, sobretudo aquelas relacionadas com a música popular, ele conseguiu criar novas formas de produção e recepção cultural, determinou e possibilitou a profissionalização de seus artistas e, também, impôs e organizou um mercado próprio de bens culturais. Mas as influências e determinações do rádio multiplicaramse em inúmeras formas e conteúdos, criando situações bastante ambíguas, contraditórias e conflituosas no cenário musical. Se de um lado o rádio imprimiu um ritmo anárquico e mais rápido, quase industrial, nas produções musicais com objetivo de atender as crescentes demandas da massa de ouvintes em formação e dos emergentes programas radiofônicos; de outro, também permitiu o escoamento de uma rica produção musical iniciada e existente no centro urbano em expansão desde o começo do século. O rádio também nasceu em São Paulo atento a um tipo de cultura que tinha sua origem na oralidade (a canção popular, a narrativa, o humor, a diversidade de sentidos) e que foi transportada para a radiofonia.

Parece que o rádio, mesmo no início de sua formação como meio de comunicação de massa em meados da década de 1930, conseguiu determinar modas e criar gostos, impondo gêneros e certa estandartização na música popular, "regredindo a audição das massas”, como quer Adorno (ADORNO, 1980). Contudo, de modo diferente do que afirmou e imaginou o filósofo alemão e saltando fora de seus fechados esquemas interpretativos, o rádio no Brasil abriu espaço para que gêneros e estilos regionais urbanos originários nas camadas mais pobres se difundissem, para um quadro regional mais amplo, como ocorreu com o samba, canções sertanejas e choros. Esse fato notável permitiu, como veremos mais adiante, a diversificação e o alargamento das possibilidades de escolha dos artistas e dos ouvintes, provavelmente ampliando e desenvolvendo seu universo de escuta ao invés de regredi-lo. 
Esse novo quadro cultural em formação emergiu de forma bastante conflitante, pois a imposição de modelos de escuta começou a ganhar força cultural com o rápido desenvolvimento e penetração dos meios de comunicação. Porém, é preciso considerar também que muitas vezes esse mesmo artista popular enfrentava, a seu modo, modelos e gostos impostos pela cultura local e regional, encarados geralmente como intransponíveis pela comunidade e para quem convivia com eles. De maneira inversa, o acesso e a troca de experiências, criadas pela radiofonia e discos, apresentavam uma imensa variedade de obras e estilos que permitiam a transposição dos limites dessas formas culturais fortemente marcadas pelos aspectos regionais e locais. Deste modo, o rádio, o disco e os locais de entretenimento musical, na realidade, formaram novas relações sociais e culturais e ambientes profissionais repletos de antagonismos. Se de um lado o músico popular pôde se desenvolver, difundir e sobreviver, ainda que precariamente, de suas músicas e técnica, sem as imposições e limites das formas culturais tradicionais, ao mesmo tempo a nova realidade cultural produzida pelos meios de comunicação nascia produzindo novos modelos, limites e um ritmo quase industrial de produção e difusão.

Essas contradições, angústias e conflitos nascidos nos anos 30, marcariam de modo permanente as relações entre músicos, compositores e suas obras, e os meios de comunicação e, conseqüentemente, a trajetória da música popular nas décadas seguintes.

\section{Multiplicação e expansão da radiofonia paulistana}

Até os primeiros anos da década de 30 , a radiofonia no Brasil funcionou de forma semi-amadora nas grandes cidades do país. Nos seus primórdios, o rádio brasileiro era feito por um pequeno número de pessoas, uma elite interessada nos seus aspectos técnicos e/ou com objetivos fundados claramente em diretrizes educativas e de difusão da "alta cultura". Os primeiros decretos ordenadores da radiodifusão nacional - o de 1924, e o seu substituto, de 1931 (D.L. 20.047) - determinavam sua função de veiculadora de princípios exclusivamente educativos, que se refletiria até nos nomes das emissoras, que geralmente incluía o adjetivo de rádio educadora. Os princípios educativos na realidade estavam relacionados a um difuso projeto nacionalista e "civilizatório", que necessariamente levaria ao progresso da nação. $\mathrm{O}$ rádio seria, então, o instrumento privilegiado para educar e "civilizar" o povo brasileiro. Foi nesse contexto e com claras intenções educativas que o professor Roquete Pinto fundou a Rádio Sociedade do Rio de Janeiro (1923) e que também surgiu a Sociedade Rádio Educadora Paulista (1923), consideradas as primeiras emissoras brasileiras.

Em São Paulo, uma tentativa exemplar de implantação de uma rádio educativa pelo Estado, ocorreu na gestão de Fábio Prado, na prefeitura de São Paulo (1934/38). Quando ele criou o Departamento de Cultura do Município em 1936, dando o comando a Mário de Andrade, projetou para um futuro próximo a criação de uma Rádio-Escola ${ }^{2}$. Diante dos problemas e altos custos financeiros, a emissora não conseguiu implantar-se, ruindo o projeto de Mário de Andrade de estabelecer uma rádio educativa financiada pelo Estado e pela qual se irradiaria sobretudo a "boa música", popular e erudita (DUARTE, 1985, p. 66).

Sem qualquer sentido comercial, as primeiras emissoras funcionavam como sociedades, associações ou clubes, com manutenção financeira e participação realizadas mediante a colaboração dos sócios

\footnotetext{
${ }^{2}$ De acordo com o prefeito, a emissora teria por finalidade "pôr ao alcance de quem quer que seja, por meio de uma estação rádiodiffusora, palestras e cursos populares, literários ou scientificos, cursos de conferencias universitarias, emfim, tudo que possa contribuir para a expansão cultural” Prado Fábio (1936), p. 71.
} 
e associados. Elas geralmente funcionavam precária e improvisadamente em salas residenciais ou escritórios particulares, com seus participantes exercendo inúmeras funções, de técnicos a locutores. As programações eram ocasionais, com dia e hora para ocorrer. A análise de fatos jornalísticos, a audição de música erudita, a leitura de romances e poesias não atraíam número grande de ouvintes (SAMPAIO, p. 292). A linguagem utilizada nas emissoras dessa época quase sempre era a mesma da usada em atividades que não eram originalmente concebidas para o rádio, como a leitura de trechos de livros, conferências, concertos de música erudita, etc., tornando os programas, na maioria das vezes, enfadonhos e cansativos.

Geralmente os músicos, artistas e técnicos eram totalmente amadores ou semi-amadores, não recebendo dinheiro e alguns faziam questão de manter essa situação. Apesar de ter melhorado com o tempo suas relações profissionais com editoras e rádios, o pudor de Marcelo Tupinambá para discutir questões profissionais nas empresas parece que continuava nos anos 30 (ALMEIDA, 1993). O seresteiro paulistano Roberto Fioravanti trabalhou, em 1931, na rádio Educadora Paulista sem qualquer remuneração, provavelmente pela atração que o rádio exercia e também pensando em uma futura ampliação de seu espaço artístico (LUCENA, 1983). O radialista Raul Duarte afirma que antigamente certas damas da sociedade participavam dos programas, obviamente sem receber por isso: "então não era uma profissional, ia lá para se exibir ou então ajudar o rádio" (ORTIZ, 1991, p.88).

Além dessa situação, a captação das ondas radiofônicas pelo ouvinte era um problema adicional pois era bastante primitiva e difícil. Baseada em cristais captadores de ondas na galena (sulfato de chumbo) ou carburundo (silicato de carbono), com antenas precárias e fones de ouvido individuais, a escuta pelos ouvintes era um problema a mais. As memórias de Jorge Americano e D. Alice revelam as dificuldades técnicas na estrutura e no uso do aparelho, mas, sobre- tudo, permitem avaliar qual era a percepção, precariedade e os problemas enfrentados pelos simples ouvinte de rádio de galena. Para o memorialista paulistano, o aparelho parecia-lhe constituído de elementos caseiros: " uma caixinha com certa porção de galena, ligação com a instalação elétrica, dois cordões para colocar nos ouvidos e uma ponta metálica que vai sendo colocada experimentalmente sobre diversos pontos da superfície da galena até escutar o som". Essa simplicidade tecnológica permitia que o aparelho fosse "feito em casa" e além disso apareciam "livros à venda (...) para ensinar como construir em casa o seu próprio rádio”. (AMERICANO, 1963, p.247). D. Alice, de seu lado, diz como nos primórdios da radiofonia era difícil a escuta conjunta do aparelho, uma vez que todos em sua casa queriam "escutar as histórias do rádio, mas não dava porque nosso rádio tinha só dois fones, quem queria escutar punha o fone no ouvido"(BOSI, 1995, p.110).

A debilidade técnica não estava restrita apenas aos aparelhos, mas também era generalizada nas primeiras estações retransmissoras brasileiras. Amadeu Amaral ficou espantado com a estrutura da emissora que conheceu no Rio de Janeiro, nos anos 20, baseada em varas de bambu, fios de cobre e bobinas de papelão. Entretanto, "aquella carangueijola ridícula funccionava maravilhosamente"(PEREIRA, 1967, p. 48), impressionando ainda mais o imaginário da população. A tecnologia radiofônica no Brasil acompanhou com certo descompasso o desenvolvimento técnico internacional dos estúdios, aparelhos e instrumentos, que gradativamente tornava o uso do rádio mais barato. Os avanços tecnológicos baratearam os aparelhos, permitindo maior acesso e multiplicando significativamente o número de ouvintes em todo o planeta. Os preços mais acessíveis e a troca dos velhos aparelhos pelos mais modernos e sofisticados aumentaram as vendas em escala planetária.

A convergência dos fatores técnicos aliados à emergência das sociedades urbanas de massa permi- 
tiram que a indústria do rádio faturasse, no meio do turbilhão da crise de 1929, 3,5 bilhões de dólares entre aparelhos e peças (BENCHIMOL, 1995, p.67). O dado mais relevante, no entanto, é que dez anos antes essa indústria inexistia. A emergência desta incrível população de radiouvintes, com um ou dois aparelhos em lugar privilegiado dentro das residências, exigiu das emissoras pelo menos duas atitudes básicas: a profissionalização em moldes empresariais, e isto significava organização mínima e viabilidade econômica e comercial, e a diversificação da programação, afastando-se dos programas educativos e elitizados.

Por tudo isso, na passagem da década de 1920/30, as emissoras de maneira geral foram perdendo seu caráter elitista e amadorístico. Com o desenvolvimento tecnológico, novas e mais potentes emissoras surgiram com objetivos nitidamente comerciais, além de permitir e facilitar a escuta através do rádio. Rapidamente as emissoras assumiram caráter comercial, voltadas para o entretenimento e informação, tendo como modelo a radiofonia norte-americana. A avaliação do radialista César Ladeira demonstra essa condição: “ $O$ rádio está vencendo na sua finalidade de agradar. Querer educar pelo rádio era bobagem. Ninguém se atrevia ficar escutando teorias, explicações, detalhes de uma coisa grave. Educar pelo rádio, à noite, depois do jantar, devia ser proibido pelos médicos em dispepsias... Distrair - foi o lema adotado!" (LADEIRA, 1933, p.83).

A fundação das PRA-9 pelo comerciante Mayrink Veiga, no Rio de Janeiro, e, em São Paulo, da PRAR, comprada pelo empresário Paulo Machado de Carvalho, originando a Rádio Record, inauguraram um novo momento na história da radiofonia nacional, pois já tentavam seguir as novas diretrizes. Essas emissoras procuraram profissionalizar-se, mantendo, principalmente, uma programação variada e diária mais leve e de entretenimento, abrindo espaço para a propaganda de produtos para viabilizar economicamente suas estruturas, seguindo assim o modelo nor- te-americano. Entretanto, de acordo com os radialistas paulistanos Nicolau Tuma e Fausto $\mathrm{Macedo}^{3}$, a resistência à publicidade foi muito grande tanto dentro como fora das emissoras. Para seus proprietários, ela era considerada "picaretagem" e degeneradora dos princípios mais nobres de educação da população. Para o empresário anunciante, econômico nos gastos, este tipo de anúncio era algo imaterial, o que o impedia de perceber o retorno; o papel escrito, ao contrário, era palpável e confiável. De certa forma, os "reclames", através da voz, reportavam-se aos vendedores ambulantes de rua, tão comuns na cidade no início do século.

Ultrapassando as iniciativas individuais de alguns radialistas, a legislação mais frouxa em relação à propaganda foi o ponto determinante e fundamental para solidificar economicamente as empresas radiofônicas, permitindo-lhes crescer e expandir-se. Em 1932, o decreto-lei 21.111 permitiu definitivamente a veiculação de anúncios pelo rádio, seguindo o modelo norte-americano do rádio-publicitário, já que na Europa o padrão radiofônico ainda era estatal ou semi-estatal, com a cobrança de imposto oficial do ouvinte. Junto com a abertura na legislação, as grandes agências de publicidade estrangeiras, sobretudo norteamericanas como N.W. Ayer and Son (1931), a Thompson (1930), Standard (1933), MaCann-Erikson (1935) e a Interamericana (1938), sentiram-se motivadas para implantar-se ou aumentar seu volume de negócios no país. O rádio tornou-se o instrumento central de veiculação de suas idéias e propagandas de seus grandes clientes, boa parte deles de empresas estrangeiras (SANTOS, 1996/97, p. 54.). Não é sem motivo, portanto, que surgem já nos anos 30 programas nas emissoras, cujos nomes estavam literalmente vinculados ao produto, como "Calouros Kolinos", "Concurso Palmolive", etc.

\footnotetext{
${ }^{3}$ Depoimentos de Nicolau Tuma e Fausto Macedo, arquivo MIS-SP.
} 
De certo modo, essas agências também colaboraram para a profissionalização das relações comerciais na radiofonia nacional, sobretudo ao tentar ultrapassar as relações pessoais nesse tipo de comércio. Obviamente, elas já identificavam no rádio o grande instrumento de divulgação de massa que levaria a milhares de pessoas seus anúncios e produtos, aumentando o faturamento de seus clientes e delas próprias, é claro. A implementação dessas agências com suas políticas de marketing e veiculação de idéias e padrões de consumo foi uma das principais portas de entrada para transmitir o padrão e o modo de vida norte-americanos, identificados com certo tipo de "modernidade", colaborando com o processo de americanização cultural, que alcançou grande força nos anos 40, principalmente após o fim da guerra, marcando sua presença na música popular no Brasil.

Com relação à música, o aumento do faturamento proporcionado pelo crescimento da publicidade, permitiu a contratação e manutenção, por meio de salários e cachês, de elenco fixo de cantores e instrumentistas, e ainda a contratação de grandes espetáculos com os artistas mais famosos, geralmente vindos do Rio de Janeiro. O rádio-comercial paulistano caminhava para a profissionalização de seus músicos e artistas, que lentamente ocupavam espaços cada vez mais amplos nas programações diárias ${ }^{4}$.

Apesar do crescimento da propaganda e da legislação favorável à publicidade, não era tão simples, como pode parecer, conseguir patrocinadores para os programas, principalmente de música popular. Um radialista de São Paulo afirma que era "mais fácil conseguir patrocínio para um Tito Schippa e Carlo Butti, do que para um cantor de samba, mesmo o mais famoso. Os grandes anunciantes eram estrangeiros, principalmente italianos, e não tinham noção de pro-

\footnotetext{
${ }^{4}$ Idem
}

paganda. Pagavam programas para eles ouvirem e não para o público que iria comprar seu produto (...)”(PEREIRA, 1967, p.223).

A comercialização das atividades artísticas, na maioria das vezes, também apresentava muitas dificuldades para grande parte dos artistas. $\mathrm{O}$ aumento da publicidade nas emissoras não ampliava necessariamente as oportunidades para novos talentos e muito menos melhorava a vida dos artistas populares. As dificuldades que eles tinham para sobreviver somente das atividades musicais, nas rádios ou fora delas, permaneciam. Nelson Gonçalves confirma esse quadro problemático e contraditório com relação aos anúncios comerciais nas emissoras, principalmente para os jovens artistas. Ele disse: "Cantamos na Rádio Kosmos, e é bom esclarecer que, para cantar naquela emissora, o cantor tinha que arranjar anúncio... Imagine que dureza, além de cantor tínhamos que ser agenciadores de anúncios (...). Eu tinha um amigo que trabalhava na cachaça Pirassununga e ele quebrou algumas vezes meu galho. Eu arranjei o anúncio (...)” (GOMES, 1987, p.19). Geralmente os artistas negros tinham mais dificuldades ainda para entrar ou manter-se "no ar". Os programas que os mantinham como protagonistas centrais e parte do elenco fixo, divulgando certos elementos da cultura negra, tinham inúmera dificuldades para levantar patrocínio. Um radialista da época confirma tal situação ao revelar que certa vez um "anunciante, que era italiano, virou-se para mim e disse: veja lá se vou gastar o meu dinheiro para ver negro cantar! e acabou mesmo financiando uma temporada de um cantor lírico italiano (...)” (PEREIRA, 1967, p.223.).

Não obstante as visíveis e duras contradições, principalmente para os artistas de modo geral e particularmente para os populares, inúmeras emissoras, aliando estrutura comercial e desenvolvimento tecnológico, ocuparam lugar nos espaços urbanos, formando, de modo impressionante e rápido, como bem disse o radialista carioca Almiran- 
te, uma "floresta de antenas" nas cidades (ALMIRANTE, 1963, p. 59).

Em São Paulo, o fenômeno tornou-se evidente com a multiplicação das rádios pela cidade durante toda década de 1930. Até o final de 1920, havia apenas quatro sociedades radiofônicas. A primeira delas foi a Sociedade Rádio Educadora Paulista, fundada em novembro de 1923 por dois engenheiros e um comerciante, começou a funcionar nos primeiros meses de 1924. Zequinha de Abreu participou com seu grupo da primeira irradiação, ainda nos "estúdios da Frei Caneca", na residência de um dos proprietários (IKEDA, 1988). Em seguida, eles instalaram a emissora provisoriamente em uma "torrinha" do $\mathrm{Pa}$ lácio das Indústrias, de onde começaram a irradiar efetivamente os programas. Em 1926, ganharam a concessão, durante 30 anos, de um terreno da prefeitura na Rua Carlos Sampaio, nas imediações da Paulista. Começaram a erguer a sede própria com ajuda financeira de particulares e empresas ricas, entre eles o Conde Matarazzo e a RCA Victor norte-americana. No início da década de 1940, a massa falida da empresa foi comprada pelo jornalista Casper Líbero, tornandose então rádio Gazeta de São Paulo, que continuou mantendo certas características da antiga Educadora, ao se auto-proclamar como a "emissora de elite".

A Rádio Club Paulista, ou Rádio Club de São Paulo, fundada em 1924, localizada na Rua Libero Badaró. Não era exatamente uma estação transmissora de rádio, mas um clube onde os sócios reuniamse para captar e ouvir, por meio de aparelho receptor, "a boa" música nacional e estrangeira. A partir de 1925 , tentou algumas poucas e rápidas transmissões sem grande força, desaparecendo na passagem dos anos 20/30 (TOTA, 1990, p.27, 28, 44 e 45). Em fevereiro de 1934, a Rádio Club São Paulo, "uma das mais antigas do 'broadcastings'do Brasil", reiniciou suas transmissões com aparelho transmissor mais potente e o indicativo PRA-5. Os reorganizadores da emissora foram os senhores "Itagyba Santiago, Ge- raldo Gomem de Mello, Dr. Leonardo Jones Jr. e João Batista do Amaral" 5.

A Rádio Cruzeiro do Sul pertencia à família Byington, composta por tradicionais importadores e comerciantes de aparelhos eletrônicos e eletrodomésticos. Entre 1929 e 1931, ela começou a funcionar no largo da Misericórdia com bastante sucesso, principalmente porque a família Byington também era representante da gravadora Columbia no Brasil, gerenciada pelo norte-americano Wallace Downey, o que lhe garantia um bom número de artistas de renome. Mais tarde, ela transformou-se na Rádio Piratininga ${ }^{6}$. E a Rádio Record, fundada em 1928, na praça da República, por Álvaro Liberato de Macedo, foi adquirida em 1931 pelo comerciante Paulo Machado de Carvalho comprou a emissora e deu-lhe o nome de Record, um homônimo da loja de discos e aparelhos de sua família. Com ele, a emissora ganhou contornos mais comerciais e populares, tornando-se a mais poderosa empresa de radiofonia da cidade e uma das maiores do país.

Foi após a revolução de 1932 que o número de emissoras paulistanas cresceu de maneira espantosa. Na realidade, a utilização do rádio em favor da causa constitucionalista, principalmente da Rádio Record e da Cruzeiro do Sul, aproximou ainda mais a população paulistana das emissoras e, principalmente, co-

\footnotetext{
5 “O Estado de São Paulo", 14/01/1934, p. 5 e 25/01/1934, p. 5.

${ }^{6}$ A data de fundação da emissora é bastante discutível. Alguns dizem, como Saint-Clair Lopes, que ela já irradiava precariamente em 1924. J.L. Ferrete, mais cuidadoso, afirma que em 1924 e 1927 ela tentou algumas fracassadas irradiações, sendo definitivamente inaugurada, de acordo com depoimento de Ariovaldo Pires, apenas em 1929. Já Mario Ferraz Sampaio diz categoricamente que ela foi fundada em 1931, pois ele teria participado do ato de inauguração junto com Byington Jr., Wallace Downey e Ariovaldo Pires. Ver MARIO Ferraz Sampaio (1984) e FERRETE, J. L. (1985).
} 
laborou para criar o hábito de escutar rádio, sobretudo para manter-se informado. A participação política das duas emissoras paulistanas foi profunda, cotidiana e consciente, a ponto de se tornar "autêntica arma de guerra", segundo Nicolau Tuma, nos episódios políticos de 1932. De fato, as relações entre rádio e política colaboraram muito para popularizar e consolidar a presença e a importância do rádio como fenômeno de massas na metrópole paulistana após o ano de $1932^{7}$. Na realidade, os vínculos entre rádio e política já haviam se manifestado desde a segunda metade da década de 1920 em diversos países, sobretudo com a utilização do rádio em disputas eleitorais ${ }^{8}$.

$\mathrm{Na}$ América Latina, o rádio foi um instrumento determinante na expansão e consolidação dos governos populistas, sobretudo os de Perón na Argentina e Getúlio Vargas no Brasil. Se antes da instauração do Estado Novo Getúlio Vargas já sabia utilizar positivamente o rádio para a difundir as realizações de seu governo e de sua imagem, com a instauração do governo autoritário, em 1937, ele procurou dominar e

\footnotetext{
${ }^{7}$ Os depoimentos de Fausto Macedo, Nicolau Tuma e Henrique Lobo demonstram como é possível periodizar o universo do rádio em São Paulo entre antes e depois de 1932. Ver também TOTA, Antonio Pedro, 1990

${ }^{8}$ Nos EUA, o rádio foi utilizado nas eleições de 1928 e 1934, na Inglaterra, na campanha eleitoral de 1928, e na França, nas eleições de 1936. No Brasil, o rádio foi usado pela primeira vez na "vitoriosa" campanha eleitoral de Júlio Prestes para a sucessão de Washington Luís. Nesta oportunidade foi composta a marchinha "Seu Julinho Vem", de Freire Jr., gravada por Francisco Alves, que acabou alcançando grande popularidade na época. Apesar do uso político aberto nas eleições democráticas em diversos países, a partir da segunda metade dos anos 20, quem mais rapidamente percebeu a utilidade política da radiofonia para transmitir de modo mais eficiente e amplo suas idéias e aproximar-se das "massas", foram os Estados totalitários que surgiram na Europa durante a década de 1930. PIERRE Albert e ANDRÉ-Jean Tudes (1982).
}

controlar as mídias eletrônicas, ou seja, o cinema e o rádio, pois elas eram o meio "direto" para falar com as "massas". Durante os quinze anos de poder, as relações de Getúlio com o rádio e o artista/música popular foram muito ambíguas e de difícil análise. Se de certa forma ele concedeu espaços palpáveis, permitindo a expansão desses setores, por meio do decreto de 1932, que deu liberdade às rádios comerciais, ao mesmo tempo procurou dominá-los por intermédio da censura e da coerção. É interessante notar que, contrastando com a política geral intervencionista e estatizante do Estado Novo, a situação da radiodifusão comercial não foi muito alterada durante o governo autoritário de Getúlio. Ao contrário, à parte a forte censura, o regime não criou quaisquer tipos de obstáculos às emissoras comerciais durante a ditadura estadonovista, que continuaram se multiplicando e consolidando-se pelo país (GURGUEIRA, 1995, capítulo III-3). Contudo, de acordo com os paradoxos da "dialética getulista", suas tentativas de controle das mídias também foram bem reais e sistemáticas, por exemplo com a criação do DIP (1939). Através deste departamento do Estado, as perseguições, as limitações e censuras, e a imposição de estéticas e temáticas do Estado Novo foram cotidianas e severas ${ }^{9}$.

$\mathrm{Na}$ verdade, essa ambigüidade do governo de Getúlio Vargas traduz sua complexa e multifacetada personalidade política, principalmente quando relacionada com a música e os artistas populares ${ }^{10}$. Ao mesmo tempo que ampliava-se, sob seu governo, os

\footnotetext{
${ }^{9}$ Ver sobre o assunto, TOTA, Antonio Pedro (1983), HAUSEN, Dóris Fagundes (1997). GURGUEIRA, Fernando, 1995.

${ }^{10}$ Ele conseguiu, por exemplo, reverter o quadro de crítica e ataque da dupla Alvarenga e Ranchinho que, de perseguidos e censurados, passaram a tocar no Palácio do Catete, sem que isso significasse a adesão política dos dois músicos à causa trabalhista e getulista.
} 
espaços para a música popular nas rádios e nos programas oficiais, permitia-se a criação de concursos de música popular, organizava-se e premiava-se o carnaval carioca, etc., ele censurava as canções, limitava os programas radiofônicos, os artistas eram perseguidos, temáticas e estéticas eram impostas.

Apesar das nítidas relações entre a política e o desenvolvimento da radiofonia nacional e paulistana, foram dois fatores próprios do novo universo cultural que atuaram de forma mais significativa e direta para a popularização do rádio: a mudança da linguagem e a diversificação da programação, mais próxima, digamos, de certo gosto médio da população. Com a situação financeira das emissoras estruturada e o quadro político mais estabilizado, foi possível dar o passo seguinte na direção da popularização. A rádio Record, novamente, teve papel de destaque na construção desse novo panorama, pois foi a primeira a usar uma linguagem mais popular, mais familiar e próxima à maioria dos ouvintes. Os radialistas da época, entre eles César Ladeira, reconhecem o papel determinante da emissora nas inovações da programação e linguagem: "A Record merece, sem favor e indiscutivelmente, esse título de renovadora da 'broadcasting' brasileira” (LADEIRA, 1933, p.27). Talvez por isso, ele também considere de maneira geral a cidade de São Paulo como a inovadora da linguagem radiofônica, já que a agitada vida da metrópole paulistana introduziu uma forma mais "moderna" e rápida de comunicar-se. Ladeira, para reforçar sua avaliação, apresenta uma crônica de um jornalista carioca do jornal "A Platea", que afirmou: "Esse modo moderno de falar no microfone que São Paulo instituiu no país. A voz dos 'speakers' passou a ser vibrante, rápida (...), sem a preguiça de outros tempos. A prosódia é agora plástica, mutavel, exprimindo alegria, tristeza, movimento, novidade, desespero, humorismo, de acordo com o sentimento mais intimo que se irradia" (LADEIRA, Idem).
Em muito pouco tempo, as relações entre ouvintes e emissoras transformaram-se profundamente. Da elite de iniciados existente no final dos anos 20, surgiram os radiouvintes no início dos anos 30, que, na segunda metade da década, rapidamente tornaram-se o "amigo ouvinte", consumidor voraz de aparelhos, peças e, sobretudo, programas radiofônicos. Mário de Andrade comentou, em 1940, com certa desconfiança e crítica, as peculiaridades e a novidade da linguagem radiofônica em formação que pretendia alcançar o maior número de pessoas e que, por isso, "obriga o rádio a uma linguagem mista, complexa, de um sabor todo especial, a começar com o 'amigo ouvinte'(...). Uma observação: hoje todo rádio brasileiro (pelo menos o carioca) emprega o 'você' em relação ao ouvinte" (ANDRADE, 1965, p. 208). Mas não foi apenas o ouvinte que tornou-se mais próximo das emissoras e, portanto, um "amigo" que participava ativamente da vida cotidiana delas, principalmente nos programas de auditório. Parece que a amizade foi construída numa relação de mão dupla, se levarmos em conta o olhar e as sensações de Antonio A. Machado já em 1931. De acordo com ele o rádio era um dócil amigo ideal "que só nos visita quando nos apetece ouvi-lo; e desaparece instantaneamente quando começa a enfastiar-nos; e não fica zangado, quando à primeira tolice que profere, the tapamos a boca” (In, LADEIRA, 1933, p.3).

Foi um fato notável todo esse conjunto de transformações, pois imediatamente a escuta do rádio entre a população paulistana ampliou. A convergência de diversos fatores históricos políticos, econômicos e culturais, permitiu a multiplicação de emissoras pela cidade. Os conflitos políticos regionais, eixos mobilizadores da população, contribuíram para desenvolver as emissoras existentes e ampliar a audiência, sedenta por informação, criando forte identificação com uma "radiofonia paulista". A legislação aberta à propaganda viabilizou comercial e financeiramente a expansão das emissoras existentes e facilitou a cri- 
ação de novas empresas de comunicação. A linguagem mais acessível aliada à diversificação da programação criaram intimidade e identificação, possibilitando o crescimento da audiência.

Este quadro favorável do início até meados da década de 1930 contribuiu para o surgimento de diversas novas emissoras. Surgiu a Rádio Kosmos, fundada em 1934, com sede na Praça Marechal Deodoro, depois transformou-se na Rádio América. A Rádio Difusora lançou a "pedra fundamental do edifício da estação (..) no terreno situado à avenida Dr. Arnaldo (próximo ao reservatório de água)" ${ }^{11}$, nos altos do Sumaré, em 25 de janeiro de 1934. Foi a primeira emissora a se constituir como Sociedade Anônima, com gente de "gabarito", mas inexperiente na radiofonia. Desde o início procurou alcançar boa qualidade técnica e potência. Guilherme de Almeida a chamava de "a emissora do som de cristal". A Rádio Tupi foi fundada, em 1937, por Assis Chateaubriand, o grande e polêmico empresário da imprensa nacional, proprietário dos Diários Associados, os quais, em São Paulo, eram representados pelo jornal Diário da Noite. Por isso a emissora, conhecida como a "rádio associada" ou a "cacique", pois seu símbolo era um índio, surgiu na rua 7 de Abril, sede do jornal paulista, e já com o transmissor mais potente da América Latina, 26 quilowatts (MORAIS, 1995, p. 364). A Rádio Excelsior, também fundada por Paulo M. de Carvalho, em 1934, surgiu para ser uma rádio católica, mas somente em 1938 a empresa foi vendida à Cúria de São Paulo. A Rádio São Paulo começou na residência de seu fundador, na Alameda Barão de Limeira, em 1934 e a Rádio Cultura, também fundada em 1934, iniciou sua programação na avenida São João.

\footnotetext{
${ }^{11}$ O Estado de São Paulo, 25/01/34, p. 5.
}

Há também referências a uma certa emissora denominada rádio "Fontoura" no ano de 1933, situada à Rua Manoel da Nóbrega, de origem um pouco obscu$\mathrm{ra}^{12}$. Adoniran Barbosa afirma que, por indicação do violonista Antonio Rago, sua primeira experiência em uma estação radiofônica foi justamente na rádio "dos Fontoura", parecendo sugerir que tratava-se de uma emissora cujos proprietários eram de certa família Fontoura. Por outro lado, Antonio Rago diz que ele se tornou violonista profissional, em 1935, na Rádio Cultura, propriedade da mesma "família Fontoura"

\section{2 - As metamorfoses da programação musical e radiofônica}

Em meados da década de 1930, a programação das rádios começou a variar entre programas humorísticos, jornalísticos, esportivos e de auditório até, com o predomínio da música brasileira. Os destaques das programações das emissoras paulistanas eram os programas musicais, geralmente de produção mais barata e conhecida, e de impacto sobre os ouvintes. Na verdade, a fase inicial das programações radiofônicas, na maioria dos países, foi baseada essencialmente nas canções populares simples e agradáveis para atrair novos ouvintes e também porque era mais simples transmitir músicas gravadas ${ }^{14}$. Assim, desde o início, as relações entre rádio e música popular foram inten-

\footnotetext{
12 Depoimento de Adoniran Barbosa MIS-SP. O fato de Adoniran designar rádio "dos Fontouras" nos leva a supor que a emissora, propriedade de alguma família Fontoura, devia ter algum outro nome. Os autores GOMES, Bruno (1987, p.11) e KRAUSCHE, Valter (1983, p. 20), nos concedem a mesma informação sobre o funcionamento da "ilegal" Rádio Fontoura, mas não indicam a referência, que provavelmente deve estar no depoimento do compositor no MIS-SP.

${ }^{13}$ Depoimento de Antonio Rago no Programa Ensaio-TV Cultura.

${ }^{14} \mathrm{Na}$ Inglaterra, cerca de $61 \%$ da programação em 1928 era constituída de música. Cf. Pierre Albert e André-Jean Tudesq, op. cit.
} 
sas e indissociáveis no Brasil e no restante do universo radiofônico internacional.

Em São Paulo, havia uma extensa programação musical ao vivo e/ou gravada de diversos tipos, do erudito ao sertanejo, passando pelos programas de música estrangeira. Os variados gêneros eram interpretados por cantores(as), Regionais, Orquestras, Jazz Sinfônicas, etc. Apesar de existirem diversos programas destinados às colônias e imigrantes estrangeiros, a preponderância ao longo da década de 1930 era de programas de música brasileira ${ }^{15}$. No transcorrer dos ano 30, era possível perceber a incrível diversidade e heterogeneidade que a programação das emissoras paulistanas alcançava. Em 1934, as atividades da maioria delas estendiam-se por todo o dia com diversos tipos de programas, dando um tom mais moderno e dinâmico à estrutura da programação.

Tendo como referência as grades de programação veiculadas pelo jornal "O Estado de São Paulo" na seção Radiotelephonia, percebe-se que a música estrangeira era bastante divulgada, quase diariamente, em diversos horários, mas estava geralmente restrita e confinada aos programas específicos ou "típicos"16.

\footnotetext{
${ }^{15}$ Uma canção de relativo sucesso naquela época era a valsa serenata "Ave-Maria" composta por Erothides de Campos em 1924. Foi gravada pela primeira vez, em 1926 (Odeon), por Pedro Celestino e depois regravada inúmeras vezes, inclusive por Francisco Alves. As músicas do autor eram muito tocadas pelos músicos paulistanos. Ver depoimento de João Dias Carrasqueira, Arquivo MIS-SP. Partitura em anexo da Ed. Cembra, 1952, em 3/4 em Mi menor.

${ }^{16}$ Já em meados da década de 1930 emissoras como Cruzeiro do Sul, Record e Kosmos matinham programas que revelavam a heterogeneidade musical da cidade. Alternavam-se pela grade programas musicais italiano, argentino, português, americano, alemão, espanhol, francês, russo, austríaco além, é claro, de diversificados programas com música brasileira. "O Estado de São Paulo", 24/01/1934; 12/03, 03/02, 07/04, 12/03 e 07/04/1935.
}

Além da programação baseada nos programas mais ou menos fixos, havia ainda uma outra série incrivelmente diversificada incluída, sem muita ordem, nas programações diárias. Eram apresentações de músicos, conjuntos, orquestras e cantores de músicas estrangeiras que variavam e transitavam entre diversas atividades das inúmeras emissoras. A maior parte estava dividida entre os conjuntos denominados genericamente de "jazz" e os de "tangos"17. Mas não faltavam também os cantos de "tangos e canções chilenas pelas senhoritas Medinas" ou as "canções argentinas por Alonsito", os "foxes $e$ vocaes internacionais", "duo vocal mexicano Tapia Rubio" e algumas orquestras 19 "Typica Argentina" e

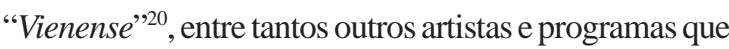
apareciam e desapareciam com a mesma rapidez nas emissoras paulistanas. A rádio Educadora Paulista, por exemplo, nos meses de janeiro e fevereiro de 1934, revezava os programas "música italiana por Marcelo Scarpadini”, "Nino Bien. Tangos” no horário das $21 \mathrm{~h} 15$ às 21h30, seguidos por "Canções americanas pela Srta. Dulce Weythig" ${ }^{21}$, que nos meses seguin-

\footnotetext{
17 “Adiós mis farras", era um tango com letra e música de Roulien, em 2/4, em Sol Maior, muito tocado desde a década de 1920. Editada por Campassi e Camin, SP, s/d. Veja referência na dedicatória ao ano de 1928. Cópia da partitura em anexo.

${ }^{18}$ Uma canção argentina de sucesso na época era "Las Tres de la Mañana, de Julian Robledo, uma Valsa com arranjo para guitarra de N. Casuscelli, em Lá Maior, Ed. Ricordi Americana, Buenos Aires, s/d. Cópia partitura em anexo.

${ }^{19}$ Como p.ex., a canção "Valência". Paso Doble em 4/4, em Re Menor, de José Padilla e letra de Lucien Boyer y Jacques-Charles. Essa música foi criada para o Mistinguett no Moulin Rouge e gravada pela Victor por José Bohr e sua Orquestra Típica (Yribarren Jazz Band), que fez a versão em castelhano. Ediciones Musicales Toledo e Perroti, Buenos Aires, s/d. Cópia da partitura em anexo. ${ }^{20}$ O Estado de São Paulo, 03,05/01/1930, 12/03,15/08, 03/02, e 07/04/1935

${ }^{21}$ O Estado de São Paulo 03 e 05/01/1934
} 
tes viriam a desaparecer. A música americana também marcava sua presença. Renato Macedo e seu irmão, cantavam música americana em alguns destes programas. Essa característica do radialista/cantor o levou a ter um programa na Excelsior, em 1941, chamado "Ecos da Broadway", no qual só tocava música gravada norte-americana ${ }^{22}$. Confirmando esse caráter heterogêneo dos programas estrangeiros e refletindo a composição social e cultural da cidade, havia na programação da rádio Kosmos em março de 1935, um programa levado ao ar, às $13 \mathrm{~h} 00$, com o sugestivo nome de "Hora Cosmopolita"23.

A expansão irreversível das rádios comerciais criou a necessidade de programas mais "populares" na grade de programação diária. Isso determinou a diminuição gradual do espaço destinado à música erudita, tornando-se mais limitado e perdendo seus privilégios na programação radiofônica. Esse fato também estava intimamente relacionado com o enfraquecimento da postura dos primórdios da radiofonia voltada para a rádio-educação, pois através da música erudita pretendia-se "elevar" o gosto da população dando-lhe acesso à "alta cultura". A permanência desse debate pode ser verificada nas posições de Otávio Gabus Mendes que, assim como César Ladeira, colocava-se contra a política de rádio educativa de maneira geral. Entretanto, ele não avalia negativamente a música erudita e reivindica espaço para a ela, mas aos moldes dos programas norte-americanos, algo que, segundo o radialista, já ocorria em São Paulo: "Há gente que diz que a música clássica é a única que deve ser usada pelo rádio como meio de educar o povo. Essa gente pensa que ouvindo Beethoven ou Bach, o espírito do povo vai se elucidando numa melhor vida intelectual. Isso é falso em

\footnotetext{
${ }^{22}$ Depoimentos de Nicolau Tuma e Fausto Macedo, MIS-SP.

${ }^{23}$ O Estado de São Paulo 12/03/1935, p. 5.
}

qualquer lugar do mundo. O rádio americano usa mais swing do que outra música. Isso porque o povo exige. No entanto, Arturo Toscaninni faz programas de rádio. Leopoldo S. também; André Kostelanetz tem esquema de colocação de orquestra que só ele usa. Eles vivem no rádio e de rádio porque há sempre momentos para a música clássica. O mesmo é o que nós fazemos aqui. Falta ainda alguma coisa, mas pouco. Em São Paulo há programas executados com mais de 40 músicos no palco" (MENDES, 1988, p.49).

Foi também, em meados dos anos 30 , que os programas de auditório com música popular ao vivo começaram a ser introduzidos nas emissoras de São Paulo, com predomínio da música brasileira. Inicialmente, as pequenas salas dos estúdios nas próprias emissoras eram adaptadas para receber a assistência, que ficava separada dos artistas e locutores pelo vidro da sala do estúdio. Já no final da década, as empresas de maior porte tinham seus grandes auditórios, onde ocorriam verdadeiros espetáculos ao vivo. A rádio Cultura, por exemplo, inaugurou, segundo impressões da época, o mais belo e luxuoso auditório na avenida São João, em 1939. O tipo de espetáculo era bastante variado, composto de música ao vivo, sobretudo brasileira. A preferência pela música nacional ${ }^{24}$ nos programas ao vivo se explica, por-

\footnotetext{
${ }^{24}$ Uma canção muito cantada na época era a "modinha" ou "canção romântica" Perdão Emília. Muitos atribuem sua autoria a Eduardo das Neves (RJ-1874-1919). Outros, como Almirante, dizem que é de José Henriques da Silva, jornalista português radicado no Rio de Janeiro, que a compôs em 1874 aos 19 anos, com melodia de Juca Pedaço. Partitura em anexo da Ed.Fermata do Brasil,. Adaptação e arranjo de João Portaro SP, em 4/4 em Ré menor, 1956. Gravação da canção de 1945 com Paragassu e Rago e seu Conjunto. Arranjo de Paraguassu, in "Saudades de Minha Terra", Evocações Produções, SP, 1988. A mesma gravação está em "Paraguassú. Noite Enluarada", Revivendo Músicas Comércio de Discos Ltda. PR, CD, s/d.
} 
que era nessa ocasião que o cidadão comum podia ver ou rever de perto seus ídolos, cantores e cantoras, interpretando suas canções favoritas.

De acordo com Nicolau Tuma, as pessoas davam muita importância aos programas ao vivo por motivos e objetivos os mais variados. A maioria frequientava os auditórios atraída pela sedução do espetáculo ao vivo. Além disso, muitos participavam dos programas para encontrar de perto seus ídolos no auditório e corredores. Alguns chegavam a freqüentá-los semanal, quinzenal ou mensalmente, como se fossem a um encontro social ou festa previamente marcada. Por fim, parte da assistência tinha também o desejo contido e ilusório de um dia compor os quadros artísticos da rádio, e acreditavam que esse era o primeiro passo.

Os programas de calouros, destinados aos aspirantes a cantores e artista de rádio de modo geral e realizados ao vivo nos auditórios, também surgiram na cidade neste período. A primeira experiência foi na rádio Cruzeiro do Sul em 1933 e sua forma inspirada nos modelos norte-americanos. Os precursores da imagem do "calouro" (no sentido de iniciante; imagem retirada daquela usada para os alunos ingressantes no tradicional curso de direito do Largo São Francisco) em São Paulo foram Ariovaldo Pires (sobrinho de Cornélio Pires, mais conhecido no meio artístico e radiofônico como Capitão Furtado) e Celso Guimarães no programa de variedades Cascatinha do Genaro. Em 1934, Capitão Furtado transferiu-se junto com o programa para uma emissora mais potente, a Rádio São Paulo, alcançando rapidamente grande sucesso. Havia ainda o Hora do Calouro, na mesma Cruzeiro do Sul, bastante freqüentado pela assistência e pelos aspirantes a cantor(a).

Otávio Gabus Mendes, ao lado de Lauro D’Ávila, comandou o programa de variedades chamado Clube Quá Quá Quarenta ${ }^{25}$, no qual, entre um sketch e

\footnotetext{
${ }^{25}$ Patrocinado por uma famosa loja de calçados da época. O quarenta referia-se ao número do calçado. Mendes Edith G.,1988, p. 49.
}

outro, cantavam os calouros. Depois ele fez, com Raul Duarte, o Há-Chá-Chá, que utilizava os mais variados critérios de avaliação dos calouros, entre eles as palmas do auditório. O memorialista Jorge Americano diz que um dos primeiros programas nesses moldes foi o "Hora da Peneira, em que se apresentavam candidatos entre os quais se peneiravam os melhores. $O$ cantor propunha-se a cantar para exibir a voz, $e$ quando desafinava batia o gongo e ele era puxado por um bengalão de gancho, entre as risadas da assistência presente no salão"(AMERICANO, 1963, p. 357).

Essa forma de espetáculo radiofônico rapidamente se expandiu pelas emissoras paulistanas, pois atraía um público bom e cativo. Surgiu na época certa polêmica e rivalidade com Ari Barroso sobre a "paternidade" da forma do "programa de calouro", já que o compositor carioca criou, em 1936, programa semelhante no Rio de Janeiro, obviamente com maior repercussão nacional. Na verdade é preciso lembrar que Ari Barroso foi contratado da rádio Kosmos de São Paulo entre outubro de 1935 e março de 1936, na qual fez, com Luís Peixoto, o programa de variedades centrado no humorismo, chamado Hora H (CABRAL, 1993, p.155 a 158). Provavelmente, foi nessa experiência paulistana que ele conheceu o programa de calouros, levando-o em seguida para o Rio de Janeiro.

Os programas com essas características eram ao vivo e freqüentados principalmente pela assistência e aspirantes a cantor(a). A ilusão, aliada a uma expectativa potencialmente real de se tornar artista, também levava às emissoras uma grande quantidade $\mathrm{e}$ variedade de pessoas. O intérprete mais famoso que participou inúmeras vezes desses programas até ser aprovado foi Adoniran Barbosa, que, de modo insistente, freqüentou o Hora do Calouro na Cruzeiro do Sul até ser aprovado cantando "Filosofia", de Noel Rosa, no fim de 1933. Os gêneros musicais de modo geral concentravam-se nos ritmos brasileiros como sambas, choros, canções sertanejas, marchinhas de carnaval e mais raramente a música estrangeira. 
O número de freqüentadores nos diversos tipos de programas de auditório cresceu significativamente ao longo da década de 1930. Para se ter uma idéia geral dessa frequiência, em 1941 a média mensal no auditório da Record foi de um pouco mais de 26.000 pessoas, perfazendo um total de quase 158.000 freqüentadores. A grande capacidade desses programas de atrair o público para seus auditórios e, sobretudo, os ouvintes, fez com que eles tivessem vida longa na radiofonia paulistana e nacional. Na realidade, houve, a partir da década de 1950, um uso exagerado desse modelo nas emissoras de todo o país e posteriormente na televisão brasileira. Degradado nos seus objetivos, forma e modelo, eles tornaram-se incapazes de descobrir novos artistas.

Os programas humorísticos, como o de "Nhô Totico", que passou pela Educadora e Rádio Cultura, também alcançaram muito sucesso nos anos 30 . Em São Paulo, os programas de humor permaneceram em destaque nas emissoras de rádio até a consolidação da TV como a principal mídia de entretenimento na passagem dos anos 50/60. Neste universo, talvez a dupla Osvaldo Moles e Adoniran Barbosa tenha sido uma das mais frutíferas, criando inúmeros programas nas décadas de 40 e 50 (Escolinha Risonha e Franca, Casa da Sogra, etc.), sendo o mais famoso e de maior sucesso o "Histórias das Malocas”. Criado por Osvaldo Moles, em 1955, na Rádio Record, neste programa surgiu o conhecido personagem "Charutinho", protagonizado por Adoniran Barbosa.

Os programas sertanejos também começaram a proliferar pelas rádios paulistanas nos anos 30 e muitas vezes confundiam-se com os humorísticos, pois boa parte deles misturava os esquetes humorísticos, narração de "causos" e histórias, sempre acompanhados por muita música regional paulista. Na realidade, esse esquema de programa reproduzia as apresentações de Cornélio Pires realizadas nas primeiras décadas do século, na capital e interior, em circos e teatros, que entremeavam peças teatrais com "cau- sos", piadas e música caipira. O próprio Cornélio chegou a apresentar-se em algumas emissoras, como na Record, em agosto de 1930, onde declamou algumas poesias e contos regionais em programa noturno ${ }^{26}$.

Comandados geralmente por um "caipira" ou "sertanejo" com o linguajar característico do caboclo, os programas se distinguiam do restante da programação radiofônica e alcançavam sucesso e reconhecimento do ouvinte paulistano. Provavelmente, esses programas seguiam e reforçavam certa tendência do humor em São Paulo existente desde o início do século e que Elias T. Saliba definiu como uma "estilização caricatural do caipira e a busca de uma tradição popular [que] foram os traços marcantes do humor paulista no período"(SALIBA, 1993, p.52). Foi dentro deste estilo, por exemplo, que Nhô Totico manteve seu programa caipira/humorístico na rádio Educadora em 1930 e depois na Cultura. Mais tarde, em 1939, ele dirigiu, na Difusora, o famoso programa Arraial da Curva Torta, idealizado por Ariovaldo Pires, o Capitão Furtado. Como diretor e autor, Ariovaldo Pires também apoiou e produziu programas sertanejos nas rádios Cruzeiro do Sul e São Paulo.

Talvez a expressão mais bem acabada e de maior sucesso nacional desse estilo que misturava linguajar, imagem e, sobretudo, música caipira com o humorismo, tenha sido a dupla Alvarenga e Ranchinho ${ }^{27}$. Vindos de Santos em 1933 para tentar a vida artística em São Paulo, mudaram-se para o Rio de Janeiro em 1936, contratados pela rádio Tupi carioca. Seus programas na emissora e as apresentações no Cassino da Urca (1937), que mesclavam a música sertaneja com paródias e sátiras políticas, fizeram muito sucesso, mas também causaram-lhes problemas com o Estado Novo.

\footnotetext{
26 “O Estado de São Paulo”, 06/08/1930, p. 16

${ }^{27}$ Murilo Alvarenga (MG/1912 - RJ/1978) e Diésis dos Anjos Gaia, Ranchinho, (Jacareí-SP/1913 - SP/1997.
} 
Em alguns dos programas sertanejos, a vida popular da cidade era devidamente representada, apresentando o amplo espectro da realidade social e cultural paulistana, fortemente marcada pelos imigrantes. $\mathrm{Na}$ Cascatinha do Genaro, por exemplo, programa de Capitão Furtado na Cruzeiro do Sul e depois na Rádio São Paulo, havia personagens como Beppo, o italiano, o turco Elias e, é claro, diversos caipiras (FERRETE, 1985). O programa de Nhô Totico também revelava esse universo dos imigrantes, recriando-o, por exemplo, no japonezinho Soko e seu pai Sakamoto, Jorginho e seu pai Salim Fizeu e a professora Acheropita e o pai Betto Sapecca Tutto (FAUSTO, 1997, p. 146). Os "caipiras" na verdade realizavam uma espécie de "ancoragem" nesses programas. Representando a cultura e as tradições populares paulistas, eles comandavam o programa e apresentavam os outros personagens compostos via de regra pelos diversos imigrantes.

É interessante observar que as características mais originais que explicam a proliferação desses programas na cidade, ou seja, a diversidade social e cultural da cidade de São Paulo, profundamente demarcada pela presença dos imigrantes e desenraizados de modo geral, já podiam ser encontradas nos textos críticos e humorísticos de Juó Bananére. Elias T. Saliba, ao recolher diversos registros, revela como na obra de Bananére já estava latente a forma dos programas de humor que predominaram nas emissoras paulistanas desde meados da década de 1930 até o fim dos anos 50 (SALIBA, 1996). Personagens como Salim Gamons sintetizavam uma língua mesclada de árabe, judeu e armênio; o oriental Tebato Nakara, editor do jornal Taka Chumbo Shimbun, falava japonês trocando os "erres" pelos “eles"; havia também o português Pacheco D’Eca.

Esta multiplicidade de línguas que se misturavam pela cidade, utilizadas de variadas formas por Bananére, e mais tarde também por Adoniran Barbosa ${ }^{28}$, foi per-

\footnotetext{
${ }^{28}$ Ver LPs da Odeon Adoniran Barbosa $(1974,1975)$.
}

feitamente identificada por Jorge Americano no cotidiano da cidade: "Uma das coisas que me faz admitir que São Paulo já seja cosmopolita é a quantidade de línguas que se ouvem falar nas ruas, nos cafés, nos cinemas, nos clubes, sem que sequer nos voltemos por curiosidade. São línguas roucas, cheias de consoantes, ásperas, guturais, duras nos rr, estaladas, aspiradas nos hh. Outras são macias, faladas de línguas mole, apenas murmuradas, de consoantes suaves, que se distinguem uma das outras" (AMERICANO, 1963, p.130). Se o cosmopolitismo de São Paulo também se revelava na diversidade das línguas e nos estranhos modos de misturar as falas, espanta-nos saber que o cidadão paulistano não se impressionava mais diante dessa diversidade, tratando-a como um fato corriqueiro, presente no dia-a-dia da cidade.

No aspecto estritamente musical, Sorocabinha dizia que havia sido um dos primeiros a produzir um Programa Sertanejo, cantar música regional e a formar dupla para tocar nas rádios, como na Difusora e São Paulo. Alguns, como Raul Torres ${ }^{29}$, cantavam emboladas e música nordestina, porque era moda na época, mas não música sertaneja. Em 1936 ele manteve um programa que ia ao ar de duas a três vezes por semana na rádio Difusora, mas só tocava disco, pois era mais barato. Obviamente, sem patrocinador e com raros músicos sertanejos em São Paulo, Sorocabinha era obrigado a reproduzir somente os discos. No final da década, uma onda de duplas sertanejas inundou a cidade e aí eles puderam contratar os músicos. Porém, nesta época, Sorocabinha já se retirava da cidade desestimulado com o ambiente artístico e radiofônico ${ }^{30}$. Diante do sucesso nas emissoras paulistanas, surgiram no cenário radiofônico

\footnotetext{
29 "Raul Torres. Caboclo Cantadô", Revivendo Músicas Comércio de Discos Ltda. PR, LP, 1990.

${ }^{30}$ Depoimento de Sorocabinha, MIS-SP.
} 
paulistano diversos programas denominados "sertanejos", que mesclavam humor e música, que, segundo avaliação de pessoas da época, tinham qualidade e objetivos desiguais (MENDES, 1988, p.91 e FAUSTO, 1997, p.146).

Foi também na década de 1930 que o jornalismo radiofônico cresceu bastante, ocupando espaços nas programações. Porém, foi somente durante a $2 \mathrm{a}$. Grande Guerra que o "jornalismo falado" se destacou verdadeiramente nas rádios paulistanas, com os inúmeros jornais diários, informativos e opinativos. A área jornalística que mais se desenvolveu durante os anos 30 foi sobretudo a esportiva. Nesses anos o rádio tornou-se o veículo de comunicação mais importante de popularização dos esportes, inovando na linguagem e potencializando o imaginário de torcedores. O radialista Nicolau Tuma foi um dos entusiastas dos esportes nas rádios e um grande inovador na linguagem esportiva. Ele foi o precursor das irradiações "lance por lance" ou "tintim por tintim" das partidas de futebol, hoje tão comuns nas rádios de todo Brasil. Em 1931, num jogo entre paulistas e paranaenses no campo da Floresta (onde hoje é o clube Tietê), para acompanhar todas as jogadas e não deixar "vazios", ele começou a usar uma forma narrativa extremamente ágil e rápida (ganhando por isso o apelido de "speaker metralha"), inaugurando assim um estilo que ainda hoje inunda as rádios e o imaginário dos brasileiros (SAMPAIO, 1984, p.339). Além do futebol, outros esportes populares irradiados pelas emissoras paulistanas eram o turfe, acompanhado pelas corridas de automóveis e lutas de boxe.

\section{3 - O músico popular e a profissionalização}

Como se pode verificar, os avanços tecnológicos, organização administrativa e independência financeira, a diversificação da grade de programação, a relativa profissionalização de técnicos e principalmente de artistas, implicaram o rápido desenvolvimento da radiodifusão em São Paulo. Nos anos 40, o rádio paulistano estava consolidado como estrutura técnica e comercial, sobretudo como um elemento determinante da vida cultural da cidade e presente no cotidiano e imaginário da população.

Todavia, a situação profissional e artística do músico nesse novo universo da comunicação não foi simples. O músico popular na verdade pôde sentir prematuramente a opressão e fragmentação do trabalho diário nessas empresas radiofônicas, fonográficas, nos mais variados espetáculos, e nos locais de entretenimento, todos eles em franca expansão pela cidade. A vida apressada e desregrada, muitas vezes associada à boêmia, implicava o desgaste físico e emocional do artista popular, que ainda estava se adaptando a nesse novo universo. Se as empresas radiofônicas e gravadoras começavam a consumir o tempo e o trabalho dos artistas, as atividades musicais individuais ou em grupos continuavam a se reproduzir nos encontros informais de bairro, baseados em relações de amizade e parentesco, como nas rodas de choro. Porém, essas atividades tornavam-se cada vez mais, e irreversivelmente, mediadas pela profissionalização e pelo contraditório mercado de trabalho, viabilizando a sobrevivência através da música. Mas, como afirma Eric Hobsbawm, existe a crença romântica e deslocada do universo da mídia, de que as gravações, espetáculos de todos os tipos, o rádio, etc. "surgem por elas mesmas e que os músicos são alimentados por anjinhos mandados do céu, como o profeta Elias”, e os que acreditam nessa crença "devem escolher um tipo de música menos terra a terra para admirar" (HOBSBAWM, 1990, p. 173).

Em contrapartida, a sensação de liberdade por viver profissionalmente das atividades musicais já era uma realidade bastante palpável. Hobsbawm parece concordar com essas possibilidades, pois assinala que a criação da indústria moderna da música popular foi em alguns aspectos "positiva para a música popular, ainda que lesasse, exigisse muito e explorasse os 
músicos. Na medida em que transformou a música local em nacional - como fez o jazz - levou grandes artistas a um vasto público, assegurou o estímulo mútuo de estilos e idéias. Nessa medida, isto é, enquanto não se meteu com o conteúdo da arte mas apenas com sua distribuição, apenas esnobes ou saudosistas românticos terão algo em contrário" (HOBSBAWM, 1990, p.180). Assim, quando a forte interferência, seja do mercado ou da indústria da cultura ou do Estado (como no Estado Novo), recai sobre a produção do artista, modificando substancialmente sua obra em favor do lucro ou da ideologia (a trabalhista, p.ex.), as transformações artísticas foram perceptíveis e empobrecedoras.

Como se pode perceber, o novo quadro históricosocial que despontou nos anos 30 foi bem mais complexo e carregado de ambigüidades e contradições do que as aparências e assertivas fazem supor. Contrastando e ultrapassando as análises mais pessimistas, apocalípticas e negativas sobre os meios de comunicação, sem contudo aceitar as mistificadoras explicações “democráticas e integradoras", é possível aproximar-se do núcleo central das relações entre música popular e meios eletrônicos, levando em conta justamente as sutilezas de suas ambigüidades e contradições. No Brasil,

\section{FONTES}

\section{Memórias, biografias e cronistas}

ALMEIDA, Benedicto Pires, Marcelo Tupinambá. "Obra Musical de Fernando Lobo", São Paulo: Ed. do autor, 1993.

ALMIRANTE. No Tempo de Noel Rosa. Rio de Janeiro: Liv. Francisco Alves, 1963.

AMERICANO Jorge. "São Paulo Atual (1935-1962)", São Paulo: Melhoramentos, 1963.

ANDRADE, Mário. "A Linguagem Radiofônica”. In: O Empalhador de Passarinho, 2.ed. São Paulo: Livraria Martins Ed., 1965. de maneira geral, e São Paulo de forma especial, durante a década de 1930, percebe-se que as relações entre a produção musical popular e o rádio em desenvolvimento e expansão foram também, de diversas formas, bastante positivas, criativas, inventivas e duradouras, marcando definitivamente a história da cultura e da música popular brasileira. Umberto Eco já havia apontado justamente nessa direção, ao avaliar as novas relações de produção e difusão da canção popular através dos meios eletro-eletrônicos, assinalando que em muitos países (e, as vezes de maneira intrigante, parece que ele se dirige especialmente ao Brasil) elas deram "ótimos frutos (oferecendo textos de nível poético, melodias de indubitável dignidade e originalidade)" (ECO, 1990, p.300). Na verdade, no Brasil, de modo todo especial, rádio e música popular formaram uma dupla notável: o rádio difundindo e desenvolvendo a música popular, por sua vez transformado e modificado por esta. Contudo, tal afirmativa não deve servir a generalizações apressadas e reducionistas. As relações entre rádio/disco e música popular nem sempre tiveram essas características em "todos os lugares e em todos os tempos". Em cada momento ou situação histórica diferente, provavelmente tais relações assumiram características e dinâmicas distintas.
BOSI, Ecléa. Memória e Sociedade. Lembranças de Velhos. 4.ed. São Paulo: Cia. das Letras, 1995.

CABRAL, Sérgio. No Tempo de Ari Barroso. Rio de Janeiro: Ed. Lumiar, 1993.

DUARTE, Paulo. Mário de Andrade por ele Mesmo. São Paulo: Ed. Hucitec, 1985.

FAUSTO, Boris. Negócios e Ócios. Histórias da Imigração. São Paulo: Cia. das Letras, 1997. 
FERRETE, J.L. Capitão Furtado. Viola Caipira ou Sertaneja. Rio de Janeiro: MinC/Funarte, 1985.

GOMES, Bruno. Adoniran. Um Sambista Diferente. Rio de Janeiro: Ed. Funarte/Martins, 1987.

LADEIRA, César. Acabaram de Ouvir... Reportagem numa Estação de Rádio" São Paulo: Ed. Nacional, 1933.

MENDES Edith G. Octávio Gabus Mendes. Do Rádio à Televisão, São Paulo: Ed. Lua Nova, 1988.

MORAIS, Fernando. Chatô o Rei do Brasil. São Paulo: Cia. das Letras, 1995.

PRADO, Fábio. “A Administração de Fábio Prado na Prefeitura de São Paulo. Através de entrevista concedida ao O Estado de São Paulo", São Paulo: Col. Departamento Municipal de Cultura, 1936.

SAMPAIO, Mario Ferraz, "História do Rádio e da Televisão no Brasil e no Mundo". Memórias de um Pioneiro. Rio de Janeiro: Ed. Achiamé, 1984.

\section{Periódicos}

O Estado de São Paulo, 1930 a 1940

\section{Depoimentos}

Depoimentos de Adoniran Barbosa, arquivo MIS-SP

Depoimento de Antonio Rago no Programa Ensaio-TV Cultura Depoimento de Antonio Rago, arquivo MIS-SP Depoimento de João Dias Carrasqueira, arquivo MIS-SP Depoimento Fausto Macedo, arquivo MIS-SP Depoimento Henrique Lobo, arquivo MIS-SP Depoimentos de Nicolau Tuma, arquivo MIS-SP Depoimento de Sorocabinha, arquivo MIS-SP Depoimento de Paragassú, arquivo MIS-SP

\section{Partituras e Discos}

"Adiós mis farras". Letra e música de Roulien. Editada por Campassi e Camin, SP, referência na dedicatória ao ano de 1928.

"Adoniran Barbosa", Odeon, LP, 1974

"Adoniran Barbosa", Odeon, LP, 1975

Ave-Maria”. Letra e música de Erotides de Campos e Jonas Neves. Ed. Cembra, 1952.

“Garoto. Paulo Belinatti, Violão”, Discos Marcus Pereira, LP, 1986.
"História da Música Popular Brasileira", Abril Cultural, LP,1971.

"Las Tres de la Mañana, Julian Robledo, Ricordi Americana, Buenos Aires, arranjo para guitarra de N. Casuscelli, s/d

"Paraguassú. Noite Enluarada", Revivendo Músicas Comércio de Discos Ltda. PR, CD, s/d

"Perdão Emília" - Autor desconhecido. Adaptação e arranjo de João Portaro. Ed.Fermata do Brasil, SP, 1956.

"Raul Torres. Caboclo Cantadô", Revivendo Músicas Comércio de Discos Ltda. PR, LP, 1990.

"Valência". Música de José Padilla e letra de Lucien Boyer y Jacques-Charles. Ediciones Musicales Toledo e Perroti, Buenos Aires, s/d.

"Saudades da Minha Terra. Evocação", Columbia-Continental, Evocação Produção, LP, 1988.

\section{Bibliografia}

ADORNO, T. "O Fetichismo na Música e a Regressão da Audição". In: Benjamin, Adorno, Horkheimer, Habermas, Col. Os Pensadores. São Paulo: Ed. Abril Cultural, 1980.

BENCHIMOL, Augusto. Uma História da Eletrônica. São Paulo: Ed. Interciência, 1995.

BURKE, Peter. Cultura Popular na Idade Moderna. São Paulo: Cia das Letras, 1989.

CHARTIER, Roger. "Cultura Popular: Retorno a un Concepto Historiografico". In: Manuscrits, nº. 12, Gener 1994.

. "A História Cultural: entre Práticas e Representações", Capítulo 1, Lisboa-Rio de Janeiro: Difel-Betrand Brasil, 1990.

CONTIER, Arnaldo D. "Memória, História e Poder: A Sacralização do Nacional e do Popular na Música”. In: Revista Música, maio de 1991.

"Música no Brasil: História e Interdisciplinariedade. Algumas Interpretações (1926-80)”. In: Revista da Anpuh, 1993.

DARNTON, R. O Grande Massacre dos Gatos. Rio de Janeiro: Ed. Graal, 1986.

DAVIES, Natalie. Culturas do Povo. São Paulo: Paz e Terra, 1990.

ECO, Umberto. "A Canção de Consumo". In: Apocalípticos e Integrados, Série Debates nº 19, 4.ed. São Paulo: Ed. Perspectiva, 1990.

GINZBURG, Carlo. O Queijo e os Vermes. São Paulo: Cia. das Letras, 1987.

GRIGNON, C. e PASSERON, J.-C. Lo culto e lo popular. Madrid: Las ediciones de La Piqueta, 1992. 
GURGUEIRA Fernando. A Integração Nacional pelas Ondas: o Rádio no Estado Novo. Dissertação de mestrado, FFLCHUSP, 1995.

HAUSEN, Dóris Fagundes. Rádio e Política. Tempos de Getúlio e Perón. Porto Alegre: Edipucrs, 1997.

HOBSBAWM, E.J. A História Social do Jazz. Rio de Janeiro: Paz e Terra, 1990.

HUNT, Lynn. Nova história Cultural. São Paulo: Ed. Martins Fontes, 1992.

IKEDA, Alberto Tsuyoshi. Música na Cidade em Tempo de Transformação. São Paulo - 1900-1930, Dissertação de Mestrado, ECA-USP, 1988.

KRAUSHE, Walter. Música Popular Brasileira. São Paulo: Brasiliense, 1983.

LUCENA, Célia de Lucena, Bixiga, Amore Mio. São Paulo: Ed. Pannartz, 1983.

MORAES, José Geraldo Vinci.."Cidade e Cultura Urbana na Primeira República", Col. Discutindo a História do Brasil, (orgs.) Maria Ligia Prado e Maria H. Capellato, São Paulo: Ed. Atual, 1994.

. Sonoridades Paulistanas. Rio de Janeiro/São Paulo: Funarte/Ed.Bienal, 1997.

. Metrópole em Sinfonia. História, Cultura e Música Popular em São Paulo nos anos 30. Tese de Doutorado, FFLCH-USP, 1997.

ORTIZ, Renato. A Moderna tradição brasileira. Cultura e indús- tria cultural. 3.ed. São Paulo: Brasiliense, 1991. p. 88.

PIERRE Albert e ANDRÉ-Jean Tudesq. Historia de la radio y la televisón. México: Fondo de Cultura Económica, 1982. p. 47.

PEREIRA, João Baptista Borges. Cor, Profissão e Mobilidade. O Negro e o Rádio de São Paulo. São Paulo: Livraria Pioneira/ Edusp, 1967.

SALIBA, Elias Thomé. "A Dimensão Cômica do Dilema Brasileiro: Testemunhos da Bellé Époque (1890-1914)”. In: Revista Cultura-Vozes, nº 1, jan.-fev. 1993

"Juó Bananáere, o Raté do Modernismo Paulista?", Cópia da $1^{\mathrm{a}}$. versão, apresentada na SBPC, 1996.

SANTOS, Rafael José dos. "Globalização e americanidade. O caso da publicidade no Brasil dos anos 30”. In: Revista USP n ${ }^{\circ} 32$, Dossiê Sociedade de Massa e Identidade, São Paulo, 1996/97.

SEVCENKO, Nicolau. Orfeu Extático na Metrópole. São Paulo, sociedade e cultura nos frementes anos 20, São Paulo: Cia. das Letras, 1992.

THOMPSON, E.P. A formação da classe operária Inglesa. São Paulo: Paz e Terra, 1987.

TOTA, Antonio Pedro. Samba da Legitimidade, Dissertação de mestrado, FFLCH-USP, 1983.

. A Locomotiva no Ar. Rádio e Modernidade em São Paulo (1924-1934). São Paulo: Ed. PW/Secretaria de Estado da Cultura, 1990.

VOVELLE, Michel. Ideologias e mentalidades. São Paulo: Brasiliense, 1987. 